RESEARCH ARTICLE

\title{
Effect of Bio-formulations on Qualitative and Quantitative Traits of Mulberry (Morus sp.) under Different Seasons
}

Thanga Roja K*, Murugesh K A and Shanmugam R

*Department of Sericulture, Forest College \& Research Institute Tamil Nadu Agricultural University, Mettupalayam - 641301

\begin{abstract}
The experiments were conducted during, Kharif and Rabi (2018 - 2020) to investigate the effect of various bio-formulations on the quality and productivity of mulberry leaves. Among all the treatments, the maximum values of quantitative attributes such as shoot length $(145.93 \mathrm{~cm})$, internodal length $(5.33 \mathrm{~cm})$, number of leaves per shoot (35.04), fresh leaf weight per plant (719.05 g), dry leaf weight (241.28 g) and shoot yield (11.57 MT/ha/ harvest) were recorded in mulberry plants treated with EM @ 1 per cent in Kharif season. Besides, the biochemical constituents viz., total chlorophyll $\left(2.80 \mathrm{mg} \mathrm{g}^{-1}\right)$, carotenoids $\left(0.824 \mathrm{mg} \mathrm{g}^{-1}\right)$ crude protein $(27.45 \%)$, moisture (77.11\%), and moisture retention capacity (66.32\%) were notably higher in the EM treated mulberry leaves compared to control in Kharif season. The present study indicated that spraying EM @ 1 per cent on mulberry three times at 15 days interval during Kharif season helped improve the quality and yield of mulberry leaves compared to control.
\end{abstract}

Keywords: Mulberry; Kharif; Rabi; Bio-formulations ; Productivity

\section{INTRODUCTION}

Mulberry (Morus sp.) is a hardy, deep-rooted, and fast-growing perennial plant belonging to the family Moraceae. It is the sole food plant for silkworm Bombyx mori. L. The growth and development of $B$. mori is directly proportionalto the nutritional status of the mulberry leaf. Most of the sericultural farmers use inorganic inputs excessively to improve mulberry productivity, which is causing sustainable damage to the ecosystem. The application of various chemicals not only increases the cost of leaf production but also spoils the soil health status of the mulberry garden. Hence, the use of organic inputs in mulberry is essential to improve silkworm growth and cocoon quality. The application of bioformulations on mulberry as a foliar spray is the easiest way to increase mulberry leaf productivity. Studies show that the foliar applications of bioformulations to mulberry significantly enhanced the uptake of essential nutrients, plant growth regulators, and beneficial microorganisms (Wididana and Higa, 1994).

Apart from the usage of fertilizer and foliar formulations to increase productivity and nutrient quality, the season plays an important role in crop growth. In India, cropping season is classified into two main season's viz., Kharif and Rabi based on the monsoon. The Kharif-cropping season is from July -October during the southwest monsoon and the Rabi cropping season is from October-March
(Prasanna, 2014). Mulberry is a perennial crop grown throughout the year in India, particularly in southern states. However, it is presumed that the yield and nutrient status of mulberry considerably vary in different seasons (Sudhakar et al., 2000). Sufficient information is not available on the influence of seasonal variation on the growth of mulberry. Keeping in view the importance of the application of bio-formulations and their impact on crop yield due to seasonal variation, the present study is undertaken to evaluate the efficacy of different bio-formulations on the growth and productivity of mulberry during different seasons.

\section{MATERIALS AND METHODS}

The field experiments were conducted in the well-established mulberry garden with V1 variety located in the 'J' block of Forest College and Research Institute, TNAU, Mettupalayam during, 2018 - 2020 of different seasons (Kharif and Rabi). The experiment consisted of five treatments viz., panchagavya (3\%), vermiwash (2\%), effective microorganism (EM) (1\%), seriboost (0.25\%), and distilled water spray. The above formulations and, a commercially available multi-micro nutrient mixture were applied on mulberry leaves thrice at an interval of 15 days i.e., on 15, 30 and 45 days after pruning (DAP) using a knapsack sprayer. Mulberry plot sprayed with distilled water alone served as the control. Observations on growth attributes such as shoot length, number of leaver per shoot, internodal 
length, and yield attributes viz., fresh leaf weight per plant, dry leaf weight per plant, and shoot yield were recorded at the time of harvest, i.e., 60 DAP. The leaf samples were collected from each treatment on 60 DAP and various biochemical constituents were assessed through standard methodologies such as moisture and moisture retention capacity by Dandin and Jolly (1986), chlorophyll and carotenoids by Hiscox and Israelstam (1979), total nitrogen content and crude protein by Humphries (1956) and total phosphorus and potassium content by Jackson (1973). The pooled mean data was analyzed statistically using Factorial Randomized Block Design (FRBD) through SPSS software (Gomez and Gomez, 1983).

\section{RESULTS AND DISCUSSION}

The application of bio-formulations in different seasons positively impacted the qualitative and quantitative traits of mulberry. The results of the experiments are presented below.

\section{Growth attributes of mulberry \\ a.Shoot length}

Application of all the foliar formulations at specific intervals had positively influenced the shoot length (Table 1). Significantly, the highest shoot length of $134.78 \mathrm{~cm}$ was recorded in EM treated plants followed by panchagavya $(120.08 \mathrm{~cm})$ and vermiwash $(113.21 \mathrm{~cm})$ treated plants. The lowest shoot length was observed in the control $(96.52 \mathrm{~cm})$. In respect of seasons, higher shoot length of 118 . $60 \mathrm{~cm}$ was observed in Kharif than Rabi (108.05 $\mathrm{cm})$. In the interaction between treatments and seasons, maximum shoot length $(145.93 \mathrm{~cm})$ was registered in EM treated plants in Kharif. The next better treatment was panchagavya in Kharif (127.48 $\mathrm{cm})$, which was on par with EM in Rabi (123.63 $\mathrm{cm})$. The present finding was strengthened by the findings Vinoj (2008), which revealed that the foliar spray of EM at 0.1 per cent significantly increased the shoot length of mulberry $(90 \mathrm{~cm})$ on 90 DAP in Kharif (June to August).

\section{b. Number of leaves per shoot}

The number of leaves per shoot, varied considerably between various bio-formulations with the highest numbers being on EM treated plants (32.28). The next better treatments were panchagavya (27.84) and vermiwash (26.37) treated plants, which were statistically on par. The lowest number of leaves per plant was noticed on untreated plants (17.81) (Table 1). Among the different seasons, a maximum number of leaves per shoot was observed in Kharif (27.38). In the interaction between treatments and seasons, significantly, the highest number of leaves per shoot of 35.04 was recorded on EM treated plants in Kharif and the lowest (16.25) was observed on untreated plants in Rabi. The application of EM on mulberry significantly increased the number of leaves per plant as it could enhance the growth due to cell division and cell expansion (Wididana and Higa, 1994). This result is in accordance with the findings of Sudhakar et al. (2000), who reported an increased number of leaves per shoot of 29.32 due to foliar application of nitrogen-fixing bacteria on mulberry during Kharif (June to September).

\section{c. Internodal length}

Spraying bio-formulations during different seasons showed a variation in the internodal length of mulberry (Table 1). The shortened internodal length is an advantageous factor due to which the number and weight of leaves in a shoot get increased. Among various bio-formulations, a lower internodal length of $5.53 \mathrm{~cm}$ was observed in EM treated plants followed by panchagavya $(5.78 \mathrm{~cm})$ and vermiwash treated plants $(6.05 \mathrm{~cm})$, respectively. A higher internodal length of $6.26 \mathrm{~cm}$ was found in seriboost treated plants, which was statistically on par with the control $(6.15 \mathrm{~cm})$. A minimal internodal length of $5.87 \mathrm{~cm}$ was noticed among the different seasons in Kharif. Interaction between bio-formulations and seasons revealed that minimum internodal length was observed in EM treated plants at Kharif (5.33 $\mathrm{cm}$ ) and the maximum was observed in untreated plants in Rabi $(6.36 \mathrm{~cm})$. This might be due to

Table 1. Effect of bio-formulations on growth attributes of mulberry, Morus indica in different seasons

\begin{tabular}{|c|c|c|c|c|c|c|c|c|c|c|}
\hline \multirow{2}{*}{\multicolumn{2}{|c|}{ Treatments }} & \multicolumn{3}{|c|}{ Shoot length (cm) } & \multicolumn{3}{|c|}{ No. of leaves/shoot } & \multicolumn{3}{|c|}{ Internodal length (cm) } \\
\hline & & Kharif & Rabi & Mean & Kharif & Rabi & Mean & Kharif & Rabi & Mean \\
\hline Vermiwash @ 2\% & & 117.23 & 109.18 & 113.21 & 28.55 & 24.19 & 26.37 & 6.02 & 6.08 & 6.05 \\
\hline EM @ 1\% & & 145.93 & 123.63 & 134.78 & 35.04 & 29.52 & 32.28 & 5.33 & 5.74 & 5.53 \\
\hline Panchagavya @ 3\% & & 127.48 & 112.67 & 120.08 & 30.41 & 25.26 & 27.84 & 5.75 & 5.80 & 5.78 \\
\hline Seriboost @ 0.25\% & & 105.06 & 99.05 & 102.06 & 23.52 & 20.83 & 22.18 & 6.15 & 6.18 & 6.26 \\
\hline Control & & 97.31 & 95.72 & 96.52 & 19.37 & 16.25 & 17.81 & 6.12 & 6.36 & 6.15 \\
\hline \multirow[t]{2}{*}{ Mean } & & 118.60 & 108.05 & 113.33 & 27.38 & 23.21 & 25.29 & 5.87 & 6.03 & 5.95 \\
\hline & $\mathrm{T}$ & & $4.12 * *$ & & & $1.56 * *$ & & & $0.12 *$ & \\
\hline \multirow[t]{2}{*}{$\mathrm{CD}(\mathrm{P}=0.05)$} & $\mathrm{S}$ & & $2.60 *$ & & & $2.35 * *$ & & & $0.05^{*}$ & \\
\hline & TXS & & $5.82 *$ & & & $3.79 * *$ & & & $0.12 * *$ & \\
\hline
\end{tabular}

* Significant; ** Highly significant.

Values are the mean of four replications and pooled mean of two crops.

$107|10-12| 2$ 
the hot and humid weather that prevailed in Kharif season, favoring minimum internodal length and more vegetative growth. Ganeshkeremane et al. (2004) also recorded minimum internodal length with the foliar spray of EM on mulberry. The various biometric characters such as vine length, number of leaves per plant, and fresh shoot weight were found to be higher in Kharif than Rabi on sweet potato (Nedunchezhiyan and Byju, 2005). These findings are in parity with the present observations.

\section{Yield attributes of mulberry}

\section{a. Fresh leaf weight per plant}

Fresh leaf weight per plant was observed to be significantly higher than all treatments in the case of EM-treated plants (710.31 g) (Table 2). The next better treatments were panchagavya (691.52 g) and vermiwash (687.90 g) treated plants, which were statistically on par with each other. Improvement in fresh leaf weight per plant ranged from 7.15 to 12.97 per cent over the control (628.75g). In comparison to two seasons, mulberry plants during Kharif recorded more fresh leaf per plant than in Rabi. Concerning the interaction between bio-formulations and seasons, maximum fresh leaf weight per plant (719.05 g) was noted in EM-treated plants during Kharif. This is followed by EM treated plants in Rabi (701.57 g), panchagavya (697.25 g) and vermiwash (692.54 g) treated plants during Kharif which were found to be on par with each other. Minimum fresh leaf weight per plant was observed in untreated plants during Rabi (672.95 g), which was statistically on par with untreated plants during Kharif (683.91 g). The present result corroborates with the findings of Sudhakar et al. (2000), who observed the fresh leaf weight per plant of $364.60 \mathrm{~g}$ due to the foliar application of nitrogen fixing bacteria on mulberry during the rainy season.

\section{b. Dry leaf weight per plant}

Among different treatments, significantly higher dry leaf weight per plant was recorded in EM treated plants (235.71 g) than in control (167.91 g) (Table 2). There was no significant difference in the dry leaf weight per plant with respect to different seasons. However, a significant variation was observed in the interaction effect between treatments and seasons. The EM treated plants during Kharif recorded more dry leaf weight per plant of $241.28 \mathrm{~g}$ significantly. The next best treatment was EM treated plants during Rabi (230.13 g), which was on par with panchagavya treated plants during Kharif (226.04 g). The present observations are in parity with the findings of Vinoj (2008), who registered that the foliar application of EM along with bio-fertilizers on mulberry significantly increased dry leaf weight per plant (184.48 g).

\section{c. Shoot yield}

The application of various formulations on foliage elucidated a positive influence on the yield-related attributes of mulberry (Table 2). In the present experiments, the results showed that EM treated plants recorded significantly highest shoot yield of $10.92 \mathrm{MT} / \mathrm{ha} /$ harvest followed by panchagavya (10.04 MT/ha/harvest) and vermiwash (9.58 MT/ ha/harvest) treated plants. The lowest yield of 8.60 $\mathrm{MT} / \mathrm{ha} /$ harvest was noticed on seriboost treated plants. Among different seasons, Kharif increased the shoot yield by 8.17 per cent over Rabi. The interaction between treatments and seasons proved that the maximum shoot yield of $11.57 \mathrm{MT} / \mathrm{ha} /$ harvest was noticed on EM-treated plants during Kharif. The second better treatments were EM treated plants during Rabi (10.26 MT/ha/harvest) and panchagavya treated plants during Kharif (10.34 $\mathrm{MT} / \mathrm{ha}$ /harvest), which were found to be on par with each other. Untreated plants during Rabi recorded the minimum shoot yield of $9.30 \mathrm{MT} / \mathrm{ha}$ /harvest. The present result falls in line with Gnanaselvi (2007), who observed an increase in the shoot yield of 6.76 per cent due to foliar application of EM at 0.1 per cent over the control. The humid weather coupled with the cloudy condition might have favored the translocation of photosynthesis towards shoot in Kharif season as observed by Biswas et al. (1988). The findings of Sengupta et al. (1982) show that the foliar application of nitrogen-fixing microorganisms had positively influenced the crop productivity also strengthened the present observations.

Table 2. Effect of bio-formulations on yield attributes of mulberry, $M$. indica in different seasons

\begin{tabular}{|c|c|c|c|c|c|c|c|c|c|c|}
\hline \multirow{2}{*}{\multicolumn{2}{|c|}{ Treatments }} & \multicolumn{3}{|c|}{$\begin{array}{l}\text { Fresh leaf weight per plant } \\
\text { (g) }\end{array}$} & \multicolumn{3}{|c|}{ Dry leaf weight per plant (g) } & \multicolumn{3}{|c|}{$\begin{array}{c}\text { Shoot yield } \\
\text { (MT/ha/harvest) }\end{array}$} \\
\hline & & Kharif & Rabi & Mean & Kharif & Rabi & Mean & Kharif & Rabi & Mean \\
\hline \multicolumn{2}{|c|}{ Vermiwash @ 2\% } & 692.54 & 683.26 & 687.90 & 190.90 & 197.37 & 194.14 & 10.01 & 9.58 & 9.80 \\
\hline \multicolumn{2}{|l|}{ EM @ 1\% } & 719.05 & 701.57 & 710.31 & 241.28 & 230.13 & 235.71 & 11.57 & 10.26 & 10.92 \\
\hline \multicolumn{2}{|c|}{ Panchagavya @ 3\% } & 697.25 & 685.79 & 691.52 & 226.04 & 219.98 & 223.01 & 10.34 & 9.74 & 10.04 \\
\hline \multicolumn{2}{|c|}{ Seriboost @ 0.25\% } & 678.99 & 668.40 & 673.70 & 182.68 & 189.87 & 186.28 & 9.36 & 8.75 & 9.06 \\
\hline \multicolumn{2}{|l|}{ Control } & 631.76 & 625.73 & 628.75 & 165.92 & 169.89 & 167.91 & 9.02 & 8.18 & 8.60 \\
\hline \multicolumn{2}{|l|}{ Mean } & 683.92 & 672.95 & 678.43 & 201.36 & 201.45 & 201.41 & 10.06 & 9.302 & 9.68 \\
\hline \multirow{3}{*}{$C D(P=0.05)$} & $\mathrm{T}$ & \multicolumn{3}{|c|}{$8.55 * *$} & \multicolumn{3}{|c|}{$5.00 * *$} & \multicolumn{3}{|c|}{$0.19 * *$} \\
\hline & $\mathrm{S}$ & \multicolumn{3}{|c|}{$5.78 *$} & \multicolumn{3}{|c|}{$4.32 * *$} & \multicolumn{3}{|c|}{$0.12 *$} \\
\hline & $\mathrm{T} \times \mathrm{S}$ & \multicolumn{3}{|c|}{$13.76 *$} & \multicolumn{3}{|c|}{$8.67 *$} & \multicolumn{3}{|c|}{$0.27 *$} \\
\hline
\end{tabular}

* Significant; ** Highly significant.

Values are the mean of four replications and pooled mean of two crops. 


\section{Biochemical attributes of mulberry}

\section{a. Total chlorophyll}

A Significantly higher total chlorophyll content of $2.73 \mathrm{mg} \mathrm{g}^{-1}$ was recorded in EM treated leaves than in untreated leaves $\left(1.78 \mathrm{mg} \mathrm{g}^{-1}\right)$. The highest amount of chlorophyll was noticed among the different seasons in Kharif. Hence, the increase in total chlorophyll content was 6.88 per cent in Kharif. In respect to the interaction between treatments and seasons, EM treated leaves during Kharif recorded the higher total chlorophyll content of $2.80 \mathrm{mg}$ $\mathrm{g}^{-1}$ respectively, which was statistically superiorto all other treatments. The lowest total chlorophyll content of $1.73 \mathrm{mg} \mathrm{g}^{-1}$ respectively was observed in untreated leaves during Rabi (Table 3). The present findings corroborate with Gnanaselvi (2007), who recorded increased chlorophyll content due to foliar application of EM at 0.1 per cent on mulberry. Kumar et al. (2018) supported the present study by registering the significantly higher chlorophyll content on mung bean due to the foliar application of PGRs during Kharif season.

\section{b. Carotenoids}

Carotenoid content in foliar formulations treated mulberry leaves differed significantly from each other (Table 3). The highest carotenoid content was recorded in EM treated leaves $\left(0.808 \mathrm{mg} \mathrm{g}^{-1}\right)$ followed by panchagavya treated leaves $(0.778 \mathrm{mg}$ $\left.\mathrm{g}^{-1}\right)$ as against control $\left(0.603 \mathrm{mg} \mathrm{g}^{-1}\right)$. With respect to seasons, the mulberry leaves harvested in Kharif possessed more carotenoids. Regarding the interaction effect between treatments and seasons, maximum carotenoid content was noticed in EM treated leaves during Kharif $\left(0.824 \mathrm{mg} \mathrm{g}^{-1}\right)$, which was statistically on par with panchagavya treated leaves during the same period season $(0.822 \mathrm{mg}$ $\left.\mathrm{g}^{-1}\right)$. A minimum carotenoid level of $0.591 \mathrm{mg} \mathrm{g}^{-1}$ was noted in control during Rabi. Sudhakar et al. (2018) and Venkataramana et al. (2009) found more carotenoids in organic foliar formulations treated mulberry plants than in the untreated control, which provides a strong evidence for the present observations.

Table 3. Effect of bio-formulations on biochemical constituents of mulberry, $M$. indica in different seasons

\begin{tabular}{|c|c|c|c|c|c|c|c|c|c|c|}
\hline \multirow{2}{*}{\multicolumn{2}{|c|}{ Treatments }} & \multicolumn{3}{|c|}{$\begin{array}{c}\text { Total Chlorophyll } \\
\left(\mathrm{mg} \mathrm{g}^{-1}\right)\end{array}$} & \multicolumn{3}{|c|}{$\begin{array}{c}\text { Carotenoid } \\
\left(\mathrm{mg} \mathrm{g}^{-1}\right)\end{array}$} & \multicolumn{3}{|c|}{$\begin{array}{c}\text { Crude protein } \\
(\%)\end{array}$} \\
\hline & & Kharif & Rabi & Mean & Kharif & Rabi & Mean & Kharif & Rabi & Mean \\
\hline \multicolumn{2}{|c|}{ Vermiwash @ 2\% } & 2.49 & 2.25 & 2.37 & 0.736 & 0.715 & 0.726 & 23.87 & 21.43 & 22.65 \\
\hline \multicolumn{2}{|l|}{ EM @ 1\% } & 2.80 & 2.65 & 2.73 & 0.824 & 0.793 & 0.808 & 27.45 & 24.39 & 25.92 \\
\hline \multicolumn{2}{|c|}{ Panchagavya @ 3\% } & 2.44 & 2.36 & 2.40 & 0.822 & 0.732 & 0.778 & 24.01 & 22.45 & 23.23 \\
\hline \multicolumn{2}{|c|}{ Seriboost @ 0.25\% } & 2.11 & 1.92 & 2.02 & 0.618 & 0.607 & 0.613 & 21.48 & 19.59 & 20.54 \\
\hline \multicolumn{2}{|l|}{ Control } & 1.83 & 1.73 & 1.78 & 0.614 & 0.591 & 0.603 & 19.89 & 17.39 & 18.64 \\
\hline \multicolumn{2}{|l|}{ Mean } & 2.33 & 2.18 & 2.26 & 0.722 & 0.688 & 0.705 & 23.34 & 21.05 & 22.20 \\
\hline \multirow{3}{*}{$C D(P=0.05)$} & $\mathrm{T}$ & \multicolumn{3}{|c|}{$0.15 * *$} & \multicolumn{3}{|c|}{$0.016 * *$} & \multicolumn{3}{|c|}{$1.42 * *$} \\
\hline & $\mathrm{S}$ & \multicolumn{3}{|c|}{$0.03 * *$} & \multicolumn{3}{|c|}{$0.010 * *$} & \multicolumn{3}{|c|}{$1.27 *$} \\
\hline & $\mathrm{T} \times \mathrm{S}$ & \multicolumn{3}{|c|}{$0.16 * *$} & \multicolumn{3}{|c|}{$0.022 *$} & \multicolumn{3}{|c|}{$2.40 *$} \\
\hline
\end{tabular}

Values are the mean of four replications and pooled mean of two crops.

\section{c. Crude protein}

Among the different treatments, maximum level of crude protein was registered in EM treated leaves $(25.92 \%)$ and minimum level was observed in control (18.64\%). In Kharif, the increment of crude protein was by 10.88 per cent over Rabi. In the interaction between treatments and seasons, EM treated leaves during Kharif recorded the highest crude protein content of 27.45 per cent. The next better treatments have EM treated leaves during Rabi (24.39\%), panchagavya (24.01\%) and vermiwash (23.87\%) treated leaves during Kharif, which were on par with each other (Table 3). The lower crude protein of 19.89 and 17.39 per cent was noticed in untreated leaves during Kharif and Rabi respectively, which were found to be on par with seriboost treated leaves during Rabi season (19.50 $\%)$. These results are in accordance with the findings of Vijayan et al. (2007), who reported higher crude protein content in the mulberry leaves, treated with Azotobacter chrococcum as a foliar spray.

\section{d. Moisture}

There was a significant improvement in the moisture content of leaves due to spraying of EM (75.97\%) over control (69.18\%) (Fig 1). This was followed by panchagavya (74.15\%) and vermiwash (73.62\%) which were found to be statistically on par with each other. The application of EM on mulberry increased the moisture content by 9.81 per cent over control. Kharif season retained a maximum quantity of moisture in mulberry than Rabi. In an interaction between treatments and seasons, significantly higher moisture was found in EM during Kharif $(77.11 \%)$. The next best treatments were panchagavya during Kharif (75.13\%), EM during Rabi (74.82 \%), and vermiwash during Rabi (74.19 $\%$ ) which were found to be on par with each other. The present results fall in line with the findings of Venkataramana et al. (2009) and Pooncli and TIzcmjcwur (2012), who observed that the mulberry

$107 \mid 10-12$ | 4 
plants applied with phosphate solubilizing bacteria as foliar spray showed an increase in moisture content $(72.16 \%)$ in the months of August September.

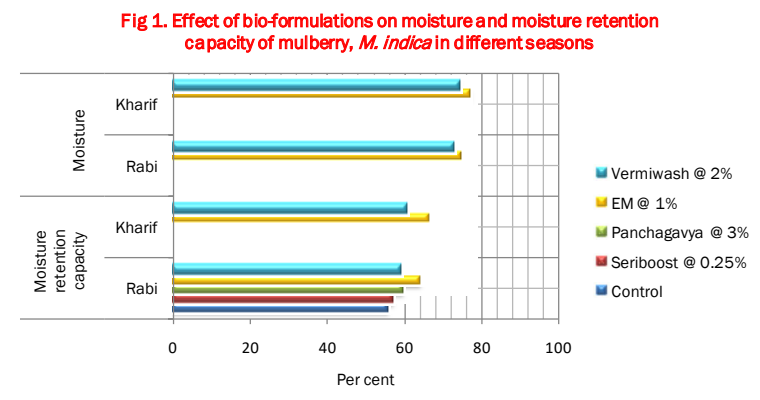

e.Moisture Retention Capacity (MRC)

Irrespective of the treatments, the enhancement of MRC in mulberry leaves due to the application of foliar formulations ranged from 3.88 to 16.67 per cent over control (Fig 1). Among the different seasons, the highest MRC of 60.79 per cent was observed in Kharif as opposed to Rabi (59.18\%). In the interaction of bio-formulations and seasons, significantly maximum MRC was recorded in EM treated leaves during Kharif (66.32\%) followed by EM treated leaves during Rabi (64.20). The minimum MRC of 56.20 and 55.68 per cent were observed in untreated leaves during Kharif and Rabi, respectively, which were found to be on par with seriboost treated leaves during Rabi (57.06\%). Sudhakar et al. (2018), who reported an increased MRC of 69.06 per cent in phosphate solublizing bacteria treated mulberry plants in the month of June - August, gave similar findings.

\section{f. Macronutrient}

The spraying of different bio-formulations significantly influenced the macronutrient content in mulberry leaves (Fig 2). The highest nitrogen content of 4.95 per cent was observed in the EM treated leaves, which was found to be statistically superior over all other treatments. Kharif registered higher nitrogen content in mulberry leaves than Rabi in respect of seasons. In the interaction of treatments and seasons, EM treated leaves at Kharif observed the maximum nitrogen content of 4.39 per cent than in control (2.78\%). A similar finding of an increase in nitrogen content on microbial inoculants treated mulberry leaves was reported by Das et al. (1994).

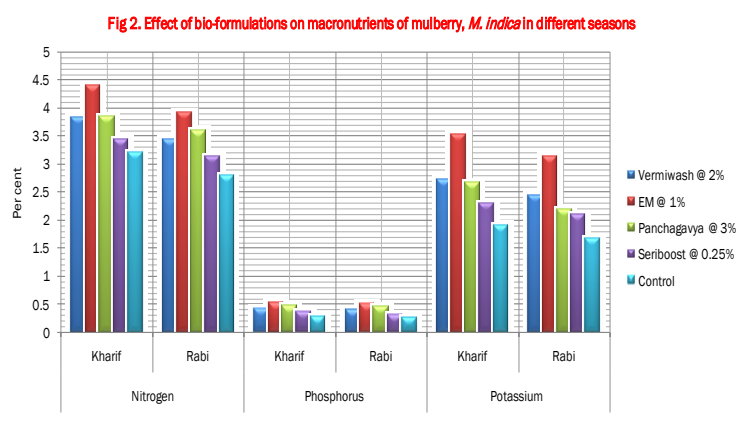

Maximum phosphorus content of 0.506 per cent was noticed in EM treated leaves followed by panchagavya, vermiwash treated leaves of 0.467 and 0.405 per cent, respectively, and minimum phosphorus content was registered in control $(0.268 \%)$. Among the seasons, a higher quantity of phosphorus was recorded in Kharif as compared to Rabi. Regarding the interaction of treatments and seasons, higher phosphorus content was documented in EM treated leaves (0.523\%) during Kharif, which was statistically superior to all other treatments.

Significantly higher potassium content of 3.32 per cent was recorded in EM treated leaves followed by vermiwash and panchagavya treated leaves of 2.57 and 2.42 per cent, respectively. Among the seasons, Kharif recorded high quantity of potassium than Rabi. Among the interaction between bioformulations and seasons, EM treated leaves during Kharif $(3.51 \%)$ showed the maximum potassium content over all other treatments. The present result falls in line with Venkataramana et al. (2009), who registered an increased phosphorous and potassium content of 0.449 and 3.43 per cent, respectively, on 70 DAP when the plants were sprayed with beneficial microorganisms as foliar spray.

\section{CONCLUSION}

It is clear from the present investigation that the application of EM @ 1 per cent thrice at the interval of 15 days i.e., 15, 30 and 45 days after pruning significantly enhanced various biometric as well as biochemical attributes of mulberry. However, the enhancement in all the characters was higher in Kharif season than in the Rabi season. EM @ 1 per cent in Kharif also improved the mulberry shoot yield by 41.44 per cent over the control.

\section{Ethics statement}

No specific permits were required for the described field studies because no human or animal subjects were involved in this research.

\section{Consent for publication}

All the authors agreed to publish the content.

\section{Competing interests}

There were no conflict of interest in the publication of this content

\section{REFERENCES}

Biswas, J., Sen, H. and Mukhopadhyay, S.K. 1988. Effect of time of planting on tuber development of sweet potato (Ipomoea batatas L. Lam). J. root crops., 14(1): 11-15.

Dandin, S.B. and Jolly, M.S. 1986. Mulberry descriptor. Sericologia, 2(6) : 465-475. 
Das, P., Ghosh, A., Katiyar, R., Rao, Y., Mathur, V., Mazumder, M. and Madhava, R. 1994. Studies on the effect of bacterial biofertilizers in irrigated mulberry (Morus alba L). Indian J. Seric.,33(2): 170-173.

Ganeshkeremane, I., Huga, I., Girish, B. and Vanitha Asharani, C.M. 2004. Use of effective microorganisms in sericulture. Indian Silk, 42(10): 9-10.

Gnanaselvi, M. 2007. Effect of foliar application of effective microorganisms (Maple) on mulberry (Morus $s p$ ) and silkworm cocoon yield. M.Phil. Thesis, Periyar University, Salem, Tamil Nadu, p. 98-101.

Gomez, K.A. and Gomez, A.A. 1983. Statistical procedure for agriculture research $2^{\text {nd }}$ Edn. John Wiley and Sons, New York, p.450-480.

Hiscox, J.T. and Israelstam, G. 1979. A method for the extraction of chlorophyll from leaf tissue without maceration. Can. J. Bot., 57(12): 1332-1334.

Humphries, E. 1956. Mineral components and ash analysis Moderne Methoden der Pflanzenanalyse / Modern Methods of Plant Analysis, p 468-502.

Jackson, M. 1973. Methods of chemical analysis: Prentice Hall of India (Pvt.) Ltd., New Delhi.

Kumar, R.K., Yadav, Nitish Sharma, Atul Yadav and Nikita Nehal. 2018. Influence of plant growth regulators on biochemical changes of mungbean (Vigna radiata L. Wilczek). J. pharmacogn. phytochem., 1(2) : 386-389

Nedunchezhiyan, M. and Byju, G. 2005. Effect of planting season on growth and yield of sweet potato (Ipomoea batatas L.) varieties. J. root crops., 31(2): 111-114.

Pooncli and TIzcmjcwur. 2012. Biochemical analysis of mulberry leaves (Morus alba L.) and silkworm Bombyx mori enriched with Vermiwash. J. Entomol., 9(5): 289-295.
Prasanna, V. 2014. Impact of monsoon rainfall on the total foodgrain yield over India. J. Earth Syst. Sci., 123(5): 1129-1145.

Sengupta, B., Nandi, A. and Sen, S. 1982. Utility of phyllosphere $\mathrm{N}_{2}$-fixing microorganisms in the improvement of crop growth. Plant Soil., 68(1): 55-67.

Sudhakar, Chattopadhyay, G., Gangwar, S. and Ghosh, J. 2000. Effect of foliar application of Azotobacter, Azospirillum and Beijerinckia on leaf yield and quality of mulberry (Morus alba). J. Agric. Sci., 134(2): 227-234.

Sudhakar, Hanumantharayappa, S.K., Kumar, J.S. and Sivaprasad, V. 2018. Organic farming through the incorporation of eco-friendly inputs under graded levels of inorganic fertilizers for sustainable mulberry (Morus alba L.) leaf production an protection.Asian.J.Sci.Tech., 9(3): 7803-7807.

Venkataramana, P., Murthy, B.N., Rao, J.K. and Kamble, C. 2009. Efficacy of foliar sprays of vermi wash and cow dung wash on biochemical and yield attributes and yield of mulberry (Morus alba L.). Karantaka. J. Agric. Sci., 22(4): 921-923.

Vijayan, K., Chakrabarti, S.P. and Ghosh, P.D. 2007. Foliar application of Azotobactor chroococcum increases leaf yield under saline conditions in mulberry (Morus sp.). Sci. Hortic., 11(3): 307-311.

Vinoj, S. 2008. Studies on the combined effect of biofertilizers, effective microorganisms and vermicompost on mulberry. M.Sc. Thesis, Periyar University, Salem, p 56-67.

Wididana. and Higa, G.N. 1994. Effect of EM on the production of vegetable crops in Indonesia. . Bulletin of Kyusei Nature Farming, 5(4): 159-170. 